\title{
BUDAYA ORGANISASI (ORGANIZATIONAL CULTURE), SALAH SATU SUMBER KEUNGGULAN BERSAING PERUSAHAAN DI TENGAH LINGKUNGAN YANG SELALU BERUBAH
}

\author{
Son Wandrial \\ Jurusan Manajemen, Fakultas Ekonomi dan Komunikasi, BINUS University \\ Jln. K.H. Syahdan No. 9, Palmerah, Jakarta Barat 11480
}

\begin{abstract}
As the world has grown more turbulent, the concept of culture has become increasingly important to organizational leaders because the new environment often calls for new values and fresh approach to doing business. Most leaders now understand that when a company's culture fits the needs of its external environment and company strategy, employee can create an organization that is tough to beat. The method used in this writing is literature study, through literature materials from several sources. There are a lot of examples in success or failure of a company based on their applied organization culture. Google is one company which success in applying adaptive culture in their organization. This example should be modified by other companies to remain in exchanging world and to reach vision and mission in the future.
\end{abstract}

Keywords: strategic management, organizational culture, competitive advantage

\begin{abstract}
ABSTRAK
Ketika dunia telah berkembang lebih bergolak, konsep budaya telah menjadi semakin penting untuk para pemimpin organisasi karena lingkungan baru sering membutuhkan nilai-nilai baru dan pendekatan segar dalam melakukan bisnis. Kebanyakan pemimpin sekarang mengerti bahwa ketika budaya perusahaan sesuai dengan kebutuhan lingkungan eksternal dan strategi perusahaan, karyawan dapat menciptakan sebuah organisasi yang sangat sulit untuk dikalahkan. Metode yang digunakan oleh tulisan ini adalah metode studi pustaka, dengan mengkaji bahan-bahan pustaka dari berbagai sumber. Banyak contoh kasus dari kesuksesan atau kegagalan sebuah perusahaan yang bersumber dari budaya organisasi yang mereka terapkan. Google adalah salah satu contoh perusahaan yang sukses karena menerapkan budaya yang adaptif di organisasi mereka. Contoh seperti ini mestinya bisa ditiru oleh perusahaan lainnya, untuk bisa bertahan dalam lingkungan yang terus mengalami perubahan dan bisa mencapai visi/misi di masa depan.
\end{abstract}

Kata kunci: manajemen strategi, budaya organisasi, keunggulan bersaing 


\section{PENDAHULUAN}

Vision is a short and inspiring statement of what your organization intends to become and to achieve at some point in the future. Buzan (2001) menyatakan visi adalah kemampuan berpikir secara stratejik atau merencanakan masa depan dengan bijak, kreatif dan imajinatif, menggunakan gambaran mental tentang situasi yang dapat dan mungkin terjadi di masa yang akan datang (future).

Visi atau misi merupakan jembatan penghubung antara waktu sekarang dengan masa depan, memberikan energi, pembakar semangat dan motivasi bagi karyawan, menjelaskan arti sebuah pekerjaan bagi karyawan. Penentuan visi atau misi yang benar dan tepat merupakan suatu gagasan yang sangat ampuh yang dapat membuat keberhasilan awal dengan memadukan segala kekuatan dari sumberdaya (resources) yang ada untuk mewujudkannya.

Sumber daya manusia adalah salah satu sumber daya utama untuk mencapai visi/misi perusahaan. Harus ada orang-orang yang memiliki komitmen tinggi untuk melaksanakan visi/misi tersebut. Dibutuhkan upaya terus-menerus dan berkelanjutan agar visi/misi perusahaan yang diterjemahkan ke dalam budaya perusahaan—yang selanjutnya diterapkan dalam bentuk perilaku dari nilai-nilai budaya (cultural value) perusahaan- benar-benar terlaksana dengan baik dan bahkan menjadi jiwa bagi seluruh pegawai yang ada di perusahaan.

Budaya organisasi sekarang ini dipandang sebagai salah satu sumber dari keunggulan bersaing perusahaan dalam menghadapi lingkungan yang terus mengalami perubahan, nilai-nilai budaya yang diterapkan dalam sebuah organisasi bisa sebagai salah satu faktor yang menentukan kelangsungan hidup sebuah organisasi.

Pada beberapa kasus, nilai-nilai budaya yang diterapkan perusahaan telah menjadi kunci kesuksesan untuk mencapai visi ataupun sebaliknya menjadi kegagalan sebuah perusahaan dalam berbisnis, kasus Enron adalah salah satunya. Sebuah perusahaan besar tapi karena menerapkan nilainilai budaya yang tamak, serakah dan menghalalkan segala cara, mengabaikan etika dan moral, telah menyebabkan Enron terpuruk dan hancur, menjadi catatan hitam dalam sejarah kejahatan korporasi di Amerika. Mesti dicatat, dari kasus Enron tersebut membuktikan pada kita bahwa nilai-nilai budaya organisasi memegang peranan yang sangat penting dalam menentukan kinerja bahkan kelangsungan hidup sebuah organisasi.

\section{METODE}

Metode yang digunakan oleh tulisan ini adalah metode studi pustaka, dengan mengkaji bahanbahan pustaka dari berbagai sumber.

\section{PEMBAHASAN}

\section{Konsep manajemen strategi, adaptasi perubahan lingkungan dan budaya}

Membahas visi dan misi perusahaan, kita tidak bisa melupakan manajemen strategi. Terdapat beberapa bentuk dari model manajemen strategi tapi hanya sedikit yang memasukan unsur budaya sebagai elemen internal utama dalam model manajemen strategi mereka. Salah satu model manajemen strategi yang memasukan unsur budaya dalam modelnya adalah dari Wheelen dan Hunger (2010). 
Manajemen strategi adalah alat untuk membuat sebuah perencanaan strategik di masa datang (future) dengan melihat semua perubahan yang terjadi pada lingkungan baik eksternal maupun internal. Model manajemen strategi menurut Wheelen dan Hunger (2010), seperti Gambar 1.

\section{Strategic Management Model}

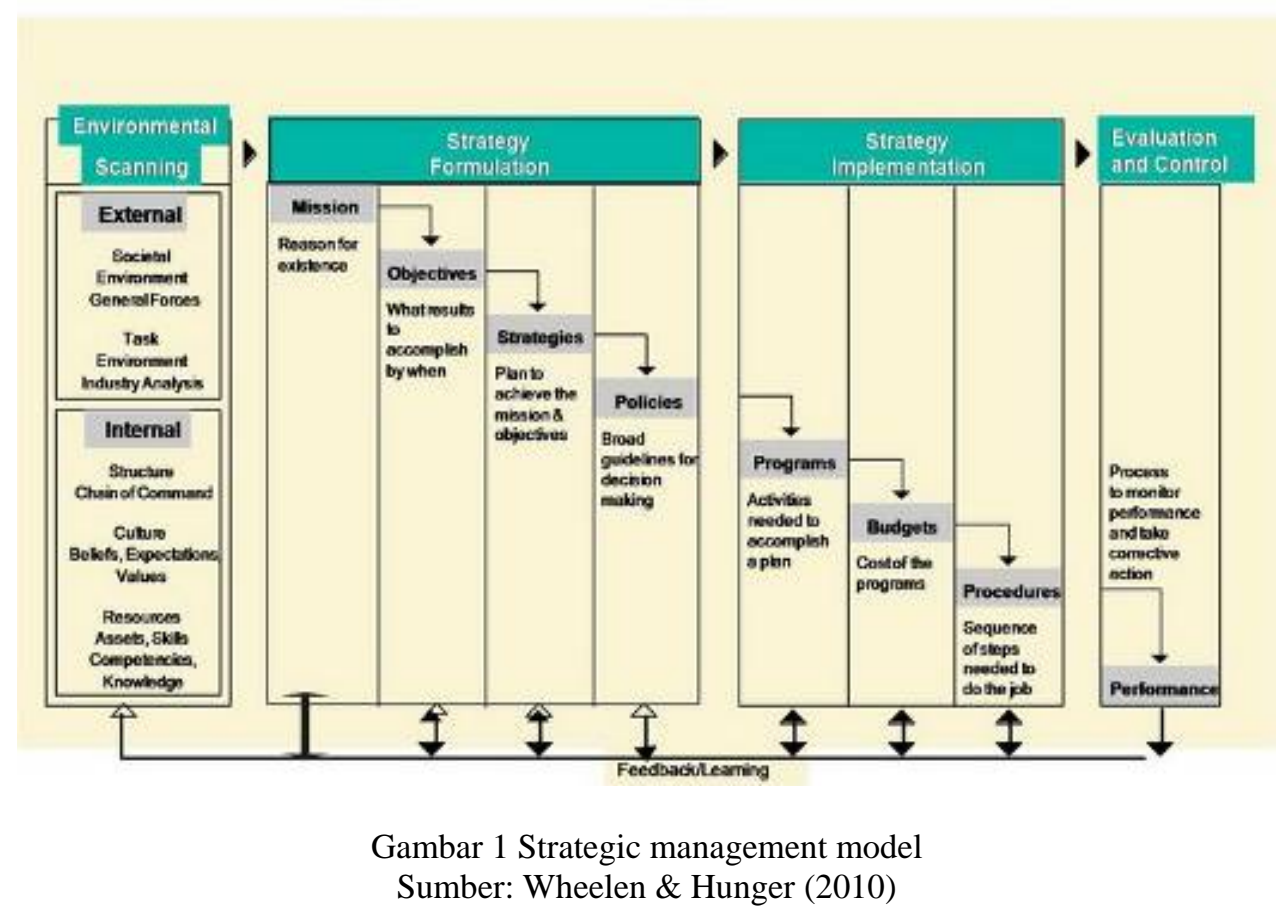

Wheelen dan Hunger (2010) mengatakan bahwa strategic management adalah"set of managerial decisions and actions that determines the long-run performance of a firm." Manajemen stratejik adalah kumpulan dari keputusan-keputusan dan tindakan yang menentukan kinerja jangka panjang dari sebuah perusahaan.

Dalam lingkungan internal atau lingkungan organisasi, Wheelen dan Hunger (2010) memasukkan tiga unsure, yaitu stuktur, budaya (culture), dan sumberdaya (resources). Menurut Wheelen dan Hunger (2010), memiliki dan mengelola sumber daya saja tidaklah cukup tapi harus didukung juga dengan struktur dan budaya yang bagus dan bisa beradaptasi dengan perubahan lingkungan. Tiga elemen internal inilah yang membedakan satu organisasi dengan organisasi lainnya, walaupun berada dalam industri yang sama. Dengan model manajemen strategi inilah, kita bisa melihat hubungan antara adaptasi perubahan lingkungan eksternal, pencapaian visi/misi dan pentingnya budaya organisasi.

Menurut Wheelen dan Hunger (2010), budaya adalah sekumpulan keyakinan, harapan dan nilai-nilai yang dipelajari dan dibagikan oleh seluruh anggota organisasi dan diajarkan dari satu generasi pegawai ke generasi pegawai yang lain. Wheelen dan Hunger (2010) memasukan unsur budaya sebagai bagian dari lingkungan internal perusahaan dalam model manajemen strateginya, dengan kata lain — dalam konteks manajemen strategi—Wheelen menganggap bahwa sebuah budaya organisasi memegang peranan sangat penting bagi kesuksesan sebuah organisasi di masa sekarang dan kelangsungan hidup perusahaan di masa depan. 
Sementara Daft (2008), mendefinsikan budaya adalah sekumpulan nilai-nilai kunci, asumsi, pemahaman, norma dan cara berpikir yang disebarkan (shared) oleh anggota organisasi dan diajarkan kepada anggota baru sebagai sesuatu yang benar.

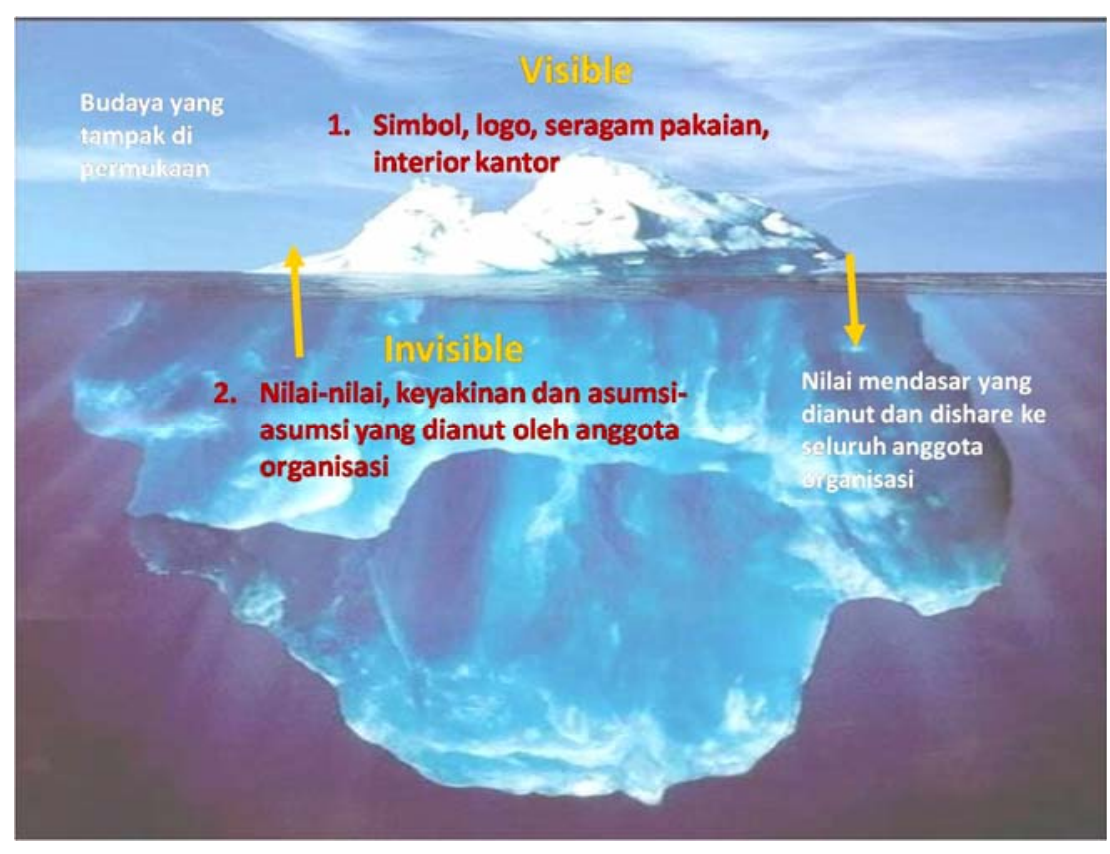

Gambar 2 Ilustrasi budaya Sumber: Daft (2008)

Daft (2008) mengilustrasikan budaya seperti gambar di atas. Ada dua bagian dari budaya: yang terlihat (visible) dan yang tidak terlihat (invisible). Budaya yang tidak terlihat memainkan peranan yang sangat besar bagi kesuksesan suatu organisasi karena di dalamnya termasuk nilai-nilai, keyakinan dan asumsi-asumsi.

Sementara menurut Schein (2004), terdapat beberapa tingkatan budaya (Gambar 3).
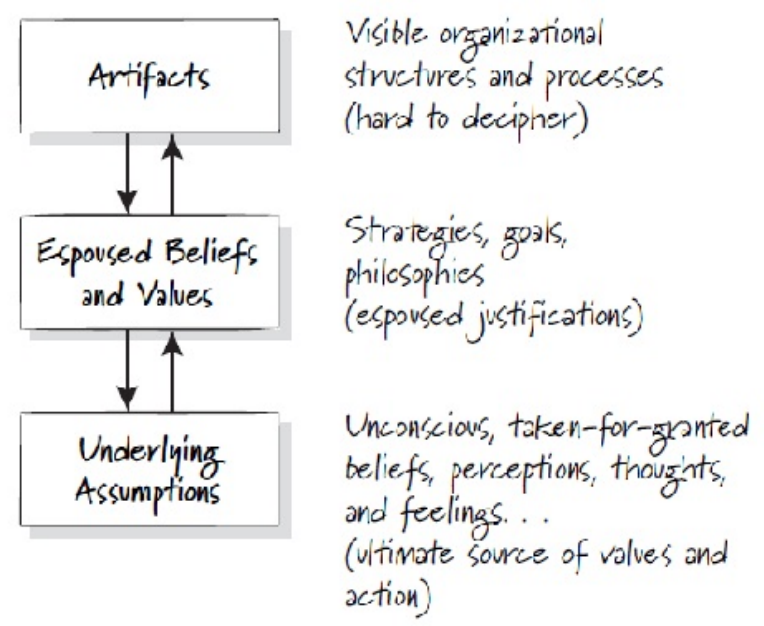

Gambar 3 Tingkatan budaya

Sumber: Schein (2004) 
Dalam Artifacts, misalnya seorang anggota baru memasuki suatu organisasi yang telah memiliki proses dan struktur organisasional yang visibel dan menghadapi suatu kelompok baru dengan budaya yang unfamiliar baginya. Artifacts mencakup produk jasa dan pelayanan bahkan pola perilakiu para anggota kelompok yang berada dalam suatu organisasi.

Espoused Values misalnya ketika karyawan baru mempertanyakan apa yang seharusnya dapat mereka berikan untuk melakukan sesuatu. Pada tingkatan ini, organisasi maupun SDMnya membutuhkan tuntunan strategi, tujuan (goals) dan filosofi-filosofi dari pemimpin organisasi. Espoused Values meliputi simbol, sejarah, jargon, seremoni dan statement of principle yang telah ditanamkan para pendirinya.

Underlying Assumptions misalnya ketika anggota organisasi percaya bahwa mereka diterima secara baik untuk melakukan sesuatu secara benar dengan cara yang tepat. Asumsi-asumsi dasar ini dapat mempengaruhi perasaan, penalaran, persepsi, kepercayaan dan pikiran bawah sadar para anggota organisasi.

Schein (2004) mengembangkan gagasan bahwa perusahaan dan budaya organisasi harus diorganisasikan dan beradaptasi untuk bisa bertahan hidup di lingkungan eksternal. Dia menggunakan istilah adaptasi eksternal untuk mengingatkan bahwa organisasi harus untuk mempertahankan diri terhadap ancaman eksternal. Baginya, perusahaan harus terus bertahan hidup dan beradaptasi, selalu belajar hal-hal baru.

\section{Mengapa Budaya Sangat Penting}

Internal integration yaitu: (1) dengan adanya budaya maka dapat menyatukan semua anggota dalam organisasi sehingga mereka tahu bagaimana untuk saling berhubungan dan bekerja sama satu dengan lainnya; (2) budaya membantu anggota organisasi untuk mengembangkan suatu kebersamaan identitas, sehingga masing-masing anggota tahu bagaimana mereka dapat berkerja sama secara efektif dan efisien; dan (3) budaya dapat menjelaskan bagaimana masing-masing anggota dapat berkomunikasi di dalam organisasi.

Eksternal adaptation yaitu: (1) budaya dapat membantu organisasi untuk beradaptasi terhadap lingkungan luar organisasi. Budaya dapat menjelaskan bagaimana suatu organisasi mempersatukan tujuan dan mencapai kesepakan dengan pihak luar; (2) nilai-nilai budaya yang benar dapat membantu organisasi untuk menanggapi respon dengan cepat terhadap kebutuhan konsumen atau mengurangi persaingan dengan pihak luar; dan (3) budaya mengikat karyawan untuk bersama dan bersatu membuat komunitas organisasi bersama daripada hanya kumpulan organisasi yang bersifat individu.

Tabel 1 menunjukan perbedaaan perilaku antara perusahaan yang menganut budaya yang adaptif dan non-adaptif terhadap perubahan lingkungan. 
Tabel 1 Perbedaan perilaku antara perusahaan budaya adaptif dan tidak adaptif

\begin{tabular}{lll}
\hline & \multicolumn{1}{c}{ Adaptive Organizational Culture } & \multicolumn{1}{c}{ Unadaptive Organizational Culture } \\
\hline \multirow{2}{*}{ Visible Behavior } & $\begin{array}{l}\text { Pemimpin mencermati semua yang } \\
\text { mendukung mereka, terutama pelanggan, } \\
\text { dan memprakarsai perubahan bila } \\
\text { diperlukan untuk melayani kepentingan } \\
\text { mereka, sekalipun hal tersebut beresiko }\end{array}$ & $\begin{array}{l}\text { Manajer cendrung bertingkah laku agak } \\
\text { picik, berbau politis dan birokratis. Sebagai } \\
\text { hasilnya mereka tidak merubah strategi } \\
\text { mereka dengan cepat untuk menyesuaikan } \\
\text { atau mengambil keuntungan dari perubahan } \\
\text { lingkungan mereka }\end{array}$ \\
& $\begin{array}{l}\text { Pemimpin sangat peduli terhadap } \\
\text { pelanggan, pemegang saham, dan } \\
\text { karyawan. Mereka juga sangat menghargai } \\
\text { orang dan proses yang dapat menciptakan } \\
\text { perubahan yang berguna (misalnya, } \\
\text { inisiatif kepemimpinan atas dan ke bawah } \\
\text { dari hirarki manajemen) }\end{array}$ & $\begin{array}{l}\text { Manajer hanya perhatikan diri mereka } \\
\text { sendiri, kelompok kerja langsung, atau } \\
\text { beberapa produk (atau teknologi) yang } \\
\text { terkait dengan kelompok kerja. Mereka } \\
\text { menghargai proses manajemen yang teratur } \\
\text { dan menghindari risiko jauh lebih tinggi dari } \\
\text { inisiatif kepemimpinan }\end{array}$ \\
$\begin{array}{l}\text { Melayani seluruh organisasi, mempercayai } \\
\text { Underlying } \\
\text { Assumption }\end{array}$ & $\begin{array}{l}\text { Memenuhi kepentingan diri sendiri dan tidak } \\
\text { orang lain }\end{array}$ & \begin{tabular}{l} 
mempercayai orang lain \\
\hline
\end{tabular} \\
\hline
\end{tabular}

\section{Empat Jenis Budaya Perusahaan}

Tidak diragukan lagi bahwa budaya memegang peranan penting bagi kesuksesan bahkan kelangsungan hidup sebuah organisasi. Kuncinya adalah selalu beradaptasi pada perubahan lingkungan eksternal perusahaan. Maka pertanyaan selanjutnya adalah budaya manakah yang cocok untuk diterapkan sebuah perusahaan, nilai-nilai budaya manakah yang penting yang lebih baik dibandingkan dengan yang lain. Untuk itu perlu dipertimbangkan faktor-faktor antara lain: lingkungan eskternal perusahaan, nilai-nilai budaya dan strategi organisasi.

Faktor eksternal perusahaan apakah dalam kondisi yang fleksibel atau stabil dan strategi perusahaaan berfokus pada eksternal atau internal. Kombinasi faktor-faktor ini akan menghasilkan empat jenis budaya perusahaan, dengan nilai-nilai (value) budaya yang berbeda.

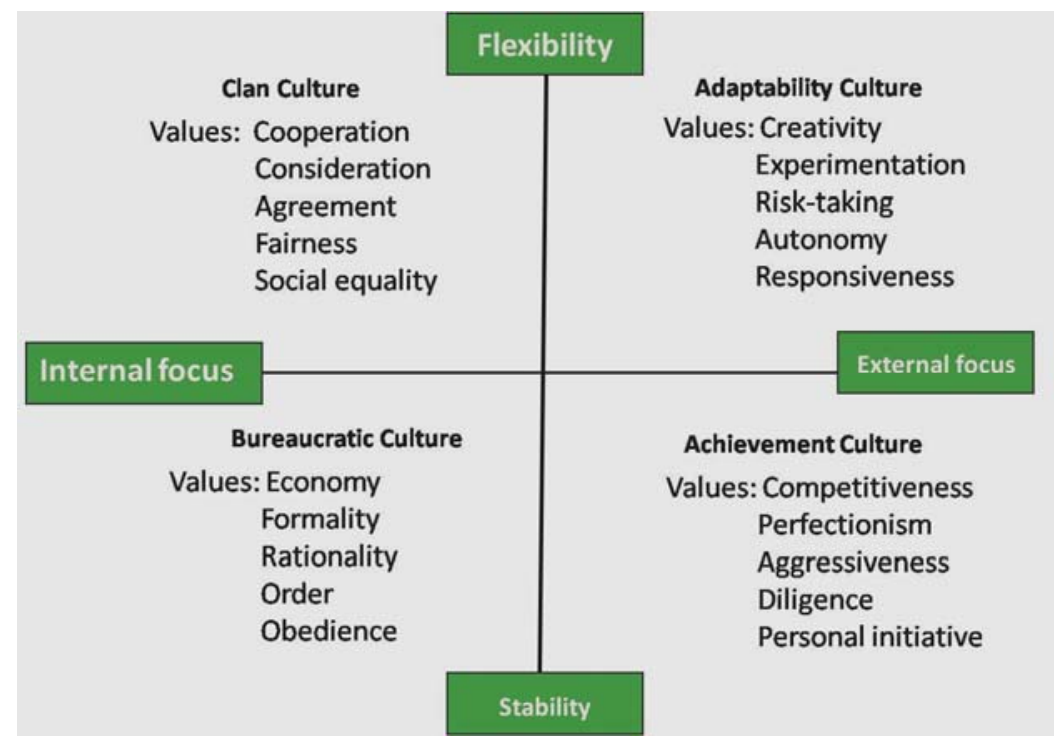

Gambar 4 Faktor eksternal perusahaan 
Budaya adaptasi (adaptation culture) ditandai oleh keadaan yang tidak stabil dengan perhatian strategi yang fokus pada kegiatan eksternal. Orang-orang dalam institusi diarahkan agar dapat mendukung kapasitas organisasi untuk menangkap tanda-tanda dan menafsirkan tindakan terhadap perubahan lingkungan. Institusi yang menganut budaya ini memerlukan respon yang segeran untuk menyesuaikan diri dengan perubahan lingkungan.

Achievement culture ini ditandai oleh keadaan lingkungan yang relatif stabil. Orang-orang diluar organisasi diperhatikan untuk menyebarkan visi dan misi organisasi kepada khalayak. Visi tersebut memberikan arti bagi para anggota dengan mendefinisikan secara jelas perannya dalam organisasi. Orang-orang dalam organisasi percaya bahwa tujuan perusahan adalah untuk melayani orang

Clan culture memfokuskan pada keterlibatan seluruh orang dalam organisasi terhadap perubahaan lingkungan yang cepat. Organisaasi membengkitkan inisiatif pada kaaryawan agar terlibat dalam kebersamaan melalui rasa tanggung jawab dan rasa memiliki dan komitmen yang tinggi terhadap organisasi. Umumnya organisasi mengijinkan karyawan bekerja tanpa jam kerja rutin sehingga karyawan bisa mengatur sendiri jadwalnya. Rasa kepemilikan dikembangkan melalui profit sharing atau gain sharing.

Bureaucratic culture dikembangkan dalam keadaan lingkungan yang stabil. Perusahaan memfokuskan strateginya ke arah internal. Simbol, kepahlawanan dan protokoler dimaksudkan untuk mendukung kerjasama dan mengikuri kebijakan institusi dalam mencapai suatu sasaran tertentu. Keterlibatan atau partisipasi individu tidak terlalu menonjol, tetapi diimbangi dengan niat baik untuk menyesuaikan diri dan kerjasama antar anggota. Kebarhasilan institusi ditentukan oleh hubungan antar bagian-bagian dan manusianya yang selalu bersatu pada dan bekerja secara efisien.

\section{Bentuk budaya adaptasi (adaptability culture) di Google}

Contoh budaya adaptif (adaptability culture) adalah budaya kerja yang diterapkan di Google (n.d.). Meskipun Google sudah banyak berkembang sejak dibuka pada tahun 1998, karyawan tetap merasa sebagai perusahaan kecil. Saat makan siang, hampir semua orang makan di kafe kantor, duduk di sembarang kursi yang masih kosong dan menikmati percakapan dengan karyawan Google dari tim yang berbeda. Komitmen terhadap inovasi tergantung pada rasa nyaman setiap orang dalam berbagi ide dan pendapat. Setiap karyawan adalah kontributor yang aktif berpartisipasi, dan setiap orang melakukan beberapa pekerjaan. Karena mereka percaya bahwa tiap karyawan Google adalah bagian yang sama pentingnya bagi kesuksesan.

Kebijakan perekrutan Google agresif dan inklusif, serta lebih mengutamakan kemampuan daripada pengalaman. Mereka mempunyai kantor di seluruh dunia dan staf Google berbicara dalam lusinan bahasa, dari bahasa Turki hingga Telugu. Hasilnya adalah tim yang mencerminkan audiens global yang dilayani Google. Saat tidak sedang bekerja, para karyawan menggeluti minatnya, mulai dari bersepeda lintas alam hingga mencicipi anggur, dari terbang hingga main frisbee.

Kantor pusat korporat Google, yang disebut Googleplex, terletak di Mountain View, California. Saat ini, kantor ini merupakan satu dari sekian banyak kami lainnya di seluruh dunia. Meski kantor-kantor Google tidak identik, namun ada beberapa elemen pokok yang sama.

Berikut hal-hal yang dapat ditemukan di tempat kerja Google: (1) ekspresi setempat dari setiap lokasi, mulai dari mural di Buenos Aires hingga gondola di Zurich, sebagai representasi kawasan dan kepribadian dari setiap kantor; (2) sepeda atau skuter untuk pergerakan yang efisien dari satu rapat ke rapat lainnya, anjing, lampu lava, kursi pijat, bola besar yang dapat digembungkan; (3) karyawan Google berbagi ruang-ruang yang berbentuk kubus, yurt, dan berjubel, dan sangat sedikit kantor 
eksklusif; (4) laptop di mana-mana, masalah standar untuk pengkodean seluler, email saat di perjalanan, dan pencatatan; (5) foosball, meja biliar, lapangan bola voli, beragam permainan video, piano, meja ping pong, dan gym yang menawarkan kelas yoga dan tari; (6) grup karyawan untuk segala minat dasar, seperti meditasi, film, mencicipi anggur, dan tari salsa; (7) makan siang dan makan malam sehat untuk semua staf di berbagai kafe; dan (8) ruangan istirahat yang dilengkapi berbagai kudapan dan minuman agar karyawan Google senantiasa bersemangat.

\section{PENUTUP}

Salah satu faktor yang membedakan antara satu organisasi dengan organisasi lainnya adalah budaya organisasi. Budaya organisasi dapat dijadikan sebagai sumber keunggulan bersaing perusahaan dalam menghadapi lingkungan yang terus berubah. Banyak contoh kasus dari kesuksesan atau kegagalan sebuah perusahaan yang bersumber dari budaya organisasi yang mereka terapkan, Enron adalah salah satu contoh dari perusahaan yang menerapkan budaya yang salah di perusahaan, sehingga membuat perusahaan tersebut harus tutup. Google adalah salah satu contoh perusahaan yang sukses karena menerapkan budaya yang adaptif di organisasi mereka, contoh seperti ini mestinya bisa ditiru oleh perusahaan lainnya, untuk bisa bertahan dalam lingkungan yang terus mengalami perubahan dan bisa mencapai visi/misi di masa depan.

\section{DAFTAR PUSTAKA}

Buzan, T. (2001). The Power of Spiritual Intelligence: 10 ways to tap into your spiritual genius. Thorsons.

Daft, R. L. (2008). Leadership. South-Western, Cengage Learning.

Emy Trimahanani. (2009). Budaya Perusahaan-Alat Ampuh Mencapai Visi.

Schein, E. H. (2004). Organizational culture and leadership. Jossey-Bass.

Wheelen, T. L., \& Hunger, J. D. (2010). Strategic management and business policy, achieving sustainability. Prentice Hall. 